Boston University School of Law Scholarly Commons at Boston University School of Law

Faculty Scholarship

2014

\title{
Health Insurance is Dead; Long Live Health Insurance
}

Wendy K. Mariner

Boston University School of Law

Follow this and additional works at: https://scholarship.law.bu.edu/faculty_scholarship

Part of the Health Law and Policy Commons

\section{Recommended Citation}

Wendy K. Mariner, Health Insurance is Dead; Long Live Health Insurance, 40 American Journal of Law \& Medicine 195 (2014). Available at: https://scholarship.law.bu.edu/faculty_scholarship/350 


\title{
Health Insurance Is Dead; Long Live Health Insurance
}

\author{
Wendy K. Mariner ${ }^{\dagger}$
}

\section{INTRODUCTION}

Upon the death of a king or queen, the proclamation "the king is dead, long live the king" announces a new monarch's accession to the throne, preserving the sovereign order. As the Patient Protection and Affordable Care Act (ACA) ${ }^{1}$ is implemented, it is tempting to proclaim the reign of a new system of health insurance. But, will it preserve the old order or initiate a new form of governance? As states and insurers grapple with new rules and regulations being issued from the Department of Health and Human Services, the Treasury Department and the Department of Labor, one might believe an entirely new health insurance system is being built. Yet, the ACA is designed to preserve existing forms of public and private health insurance, such as Medicare and private employer group health plans, which will continue to operate much as they have in the recent past. ${ }^{2}$ What has changed is the role that insurance will play and how that will shape the way we think about health policy.

Under the ACA, health insurance will function more like social insurance than conventional indemnity insurance. ${ }^{3}$ Consequently, the new queen may look more like a prime minister - no longer reigning as a sovereign, but responsible to her subjects and accountable to their governing institutions. This represents a notable change, but it is less dramatic than one might suspect, as health insurance has long functioned differently from other categories of insurance.

Health insurance no longer operates like conventional life or car insurance, as it did in the 1950s and 1960s, when health insurance began displacing direct cash payments from patients to physicians. Blue Cross and Blue Shield offered indemnity policies to reimburse patients for fees patients paid to physicians and hospitals. ${ }^{4}$ Even then, however, Blue Cross and Blue Shield characterized their policies not as

† Edward R. Utley Professor of Health Law, Boston University School of Public Health; Professor of Law, Boston University School of Law; Professor of Socio-Medical Sciences, Boston University School of Medicine; JD, Columbia University School of Law; LLM, New York University School of Law; MPH, Harvard School of Public Health

${ }^{1}$ Patient Protection \& Affordable Care Act of 2010, Pub. L. No. 111-148, 124 Stat. 119 (codified as amended in scattered sections of $21,25,26,29,42$ U.S.C.).

${ }^{2}$ See generally Paul Starr, Remedy and Reaction: The Peculiar American Struggle over HeAlth CARE REForm 177 (2011).

${ }^{3}$ See id. at 241-47.

${ }^{4}$ See generally Robert Cunningham III \& Robert Cunningham, JR., The Blues: A History of the Blue Cross And Blue Shield System (1997). 
insurance, but as hospital and medical service payment plans, respectively; and they were governed by state laws similar to, but distinct from, other insurance licensure statutes. ${ }^{5}$ As healthcare costs rose, commercial insurers entered the market with indemnity policies. In the early years, insurers typically paid whatever prices hospitals and physicians charged, but today's insurers negotiate prices with providers, and large insurers that have substantial bargaining power can set their own prices. Insurers also added managed care components to their plans to control costs, ${ }^{6}$ and in many cases insurance coverage determines the kind of care that patients receive in practice.

Today, health insurance is no longer simply a class of insurance that covers risks to health, and it has not been so for many years. ${ }^{7}$ Part II argues that health insurance has become a unique form of insurance-a mechanism to pay for healthcare that uses risk spreading as one of several pricing methods. ${ }^{8}$ Part III explains how the ACA builds on this important payment function to create a complex social insurance system to finance healthcare for (almost) everyone. Health insurance is now so integrated into the healthcare system that we can no longer have one without the other. This shift poses challenges to laws governing health insurance policies. Part IV, therefore, examines how the ACA draws on various conceptions of insurance to produce a quasi-social insurance system. Such a system poses new challenges to laws governing insurance, not all of which are resolved by the ACA itself. I conclude that, whether or not the ACA is fully implemented, health insurance has already changed - but more nuanced questions remain about whether and how laws governing insurance licensure and claims determinations should also change.

\section{CHARACTERISTICS OF HEALTH INSURANCE}

Health insurance today differs from other classes of insurance in three critical respects. ${ }^{9}$ First, it is the primary source of payment for medical care in the United States. ${ }^{10}$ Second, because everyone needs healthcare, almost everyone needs health

\footnotetext{
${ }^{5}$ Robert D. Eilers, Regulation of Blue Cross and Blue Shield Plans 135-36 (1963). For an example of such licensure statutes, see Mass. Gen. Laws ch. 176A (2012 \& Supp. 2013), 176C (2012).

${ }^{6}$ See generally Alain C. Enthoven, Health Plan: The Only Practical Solution to the Soaring Cost of Medical Care (1980); Gail Jensen et al., The New Dominance of Managed Care: Insurance Trends in the 1990's, 16 Health AfF. 125 (1997); Marsha Gold, Can Managed Care and Competition Control Medicare Costs?, W3 HeAlth AfF. 176 (2003), http://content.healthaffairs.org/content/early/2003/04/02/hlthaff.w3.176.full.pdf?origin=pub lication_d etail.

${ }^{7}$ See generally Jon Gabel et al., The Changing World of Group Health Insurance, 7 Health AfF. 48 (1988); Jon Gabel et al., Withering on the Vine: The Decline of Indemnity Health Insurance, 19 Health AfF. 152 (2000); Wendy K. Mariner, Social Solidarity and Personal Responsibility in Health Reform, 14 CONN. INS. L.J. 199, 206-13 (2008).

${ }^{8}$ Wendy K. Mariner, Health Reform: What's Insurance Got to Do with It? Recognizing Health Insurance as a Separate Species of Insurance, 36 AM. J.L. MED. 436, 438 (2010); Nat'l Fed'n of Indep. Bus. (NFIB) v. Sebelius, 132 S. Ct. 2566, 2620 (2012) (Ginsburg, J., dissenting in the judgment in part and concurring in the judgment in part).

${ }^{9}$ See generally Brief of 104 Health Law Professors as Amici Curiae in Support of Petitioners, NFIB V. Sebelius, $132 \quad$ S. Ct. $2566 \quad$ (2012), available at http://www.americanbar.org/content/dam/aba/publications/supreme_court_preview/briefs/11 -

398 petitioneramcu104healthlawprofs.authcheckdam.pdf (written together with Mark Hall, the author who organized and participated in drafting the brief (along with Abbe Gluck), the characteristics of which are described in Part II, infra.)

${ }^{10} \mathrm{Id}$. at 16 .
} 
insurance to pay for that care. ${ }^{11}$ Third, health insurance is no longer designed like conventional insurance policies and thus no longer functions like conventional insurance. ${ }^{12}$ Any one of these characteristics is enough to distinguish health insurance from conventional indemnity insurance, but together they make health insurance unique. Indeed, healthcare may be the only market that could not exist in its current form-providing today's sophisticated services-without third party payers. ${ }^{13}$

\section{A. Public and Private Coverage Pays for Most Medical Care}

Americans pay for most of their healthcare with health insurance, not cash. In 2009 , they used public and private insurance to pay for $85.7 \%$ of their personal healthcare expenditures. ${ }^{14}$ Only $12.8 \%$ was paid out-of-pocket for insurance deductibles and co-payments, over-the-counter medication costs and other health service expenses not covered by insurance. ${ }^{15}$

The vast majority of health insurance payments go directly to providers to pay for care-medical services, procedures, medications and devices. ${ }^{16}$ The practice of reimbursing patients for their out-of-pocket payments to providers is the exception today ${ }^{17}$ When a person needs medical care, her health insurance pays the physicians, hospitals and laboratories for the services rendered to the patient. In this respect, both private commercial health insurance and public benefit programs like Medicare function in the same manner. Thus, the average person is likely to think of her health plan as the entity that pays for her medical care. To be sure, insurance does not pay for some services, but these are the minority-accounting for less than fifteen percent of national personal health expenditures. ${ }^{18}$

There is no other product that is purchased with insurance benefits. One might argue that repairs to one's house or car are often paid directly by homeowners or car insurance. However, that analogy ignores an important distinction. Individuals do not seek repairs in a vacuum. First, they must buy a house or a car with money from their own assets or a loan. Then they may buy insurance to pay for any repairs needed in the future. Later, if damage occurs, they may call upon insurance to pay for repairs, but they do not use car insurance proceeds to buy the car in the first place.

In contrast, individuals seek health insurance to buy the initial "product" healthcare-before seeking that care. One might claim that health insurance is like a car loan obtained to buy the car in the first place, except that the "loan" does not have to be repaid. Health insurance is not analogous to car insurance, unless we

\footnotetext{
${ }^{11}$ See id. at 5 .

${ }^{12}$ Mariner, supra note 8, at 443.

${ }^{13}$ See Brief of 104 Health Law Professors, supra note 9, at 7-10.

${ }^{14}$ Ctrs. for Medicare \& Medicaid Servs., U.S. Dep'T of Health \& Human Servis., National Health Expenditures by Type of Service And Source of Funds, CY1960-2012, available at http://www.cms.gov/Research-Statistics-Data-and-Systems/Statistics-Trends-andReports/NationalHealthExpendData/NationalHealthAccountsHistorical.html (last modified Jan. 7, 2014)

${ }^{15}$ U.S. Census Bureau, U.S. Dep't of Commerce, Statistical Abstract of the United StATES: $\quad 2012, \quad 102 \quad$ tbl.135 (2012), available at http://www.census.gov/compendia/statab/2012edition.html (select "Section 3: Health and Nutrition" from the menu).

${ }^{16} \mathrm{Id}$. at 104 .

${ }^{17} \mathrm{Id}$. at 102 .

${ }^{18} I d$.
} 
consider the human body to be the original product and health insurance as the source of payment for repairs to the body. Of course, the human body is not a product; the Thirteenth Amendment has prohibited treating a human being as a commodity since $1865 .^{19}$

In his opinion on the ACA's individual mandate in National Federation of Independent Business v. Sebelius, Chief Justice John Roberts rejected the idea that health insurance differs from car insurance. ${ }^{20}$ Very few things are purchased for their own sake, he asserted: a car is purchased for transportation to go places. ${ }^{21}$ If health insurance is similarly purchased for an ultimate purpose, as the Chief Justice implied, that purpose can only be to buy healthcare, which, under his reasoning, is itself purchased for the further purpose of getting well. This theory makes analogies - a mainstay of legal reasoning - unmanageable. At issue is the source of payment for products or services like cars and healthcare. Intangible states of being, like going places and getting well, are not products that can be bought. Buying health insurance is at least one step too far removed from buying a car to satisfy the Chief Justice's attempt at analogy.

\section{A. The Universal NeEd for Health InsuranCE}

Insurance is used to pay for most healthcare because healthcare is often extremely expensive and unpredictable. To be sure, some other purchases can be expensive and unpredictable. But, healthcare is not an optional good. Almost everyone needs some sort of healthcare at one time or another during their lives. ${ }^{22}$

The National Center for Health Statistics (NCHS) reports that only 1\% of adults have never visited a healthcare professional in their lifetimes. ${ }^{23}$ Of course, the need for healthcare varies over a lifetime. Yet, most Americans use healthcare frequently. The same NCHS survey reports that $95.9 \%$ of adults had visited a healthcare professional within the preceding 5 years, and $82.5 \%$ had done so within the preceding year. ${ }^{24}$ Children see healthcare providers even more often. ${ }^{25}$

Much of this care is expensive. National health expenditures accounted for $17.9 \%$ of the United States GDP in 2011, totaling about $\$ 2.7$ trillion. ${ }^{26}$ Life-saving care is especially expensive, with organ transplants costing hundreds of thousands of dollars. ${ }^{27}$ Coronary artery bypass surgery cost $\$ 86,914$ at private insurance rates in

\footnotetext{
${ }^{19}$ U.S. CONST. amend. XIII.

${ }^{20}$ NFIB v. Sebelius, 132 S. Ct. 2566, 2591 (2012) (Roberts, C.J.).

${ }^{21}$ Id. See also Kenneth S. Abraham, Four Conceptions of Insurance, 161 U. PA. L. REV. 653, 671 (2013) (arguing that automobile insurance is second to health insurance in its importance to wellbeing, because "[i]n all but urban areas where there is adequate mass transit, driving is an essential feature of daily life").

${ }^{22}$ NFIB, 132 S. Ct. at 2610 (Ginsburg, J., dissenting in the judgment in part and concurring in the judgement in part).

${ }^{23}$ Nat'l Ctr. for Health Statistics, Summary Health Statistics for U.S. Adults: National Health Interview Survey, 2009, 10 VITAL \& HEALTH STAT. 1, 124 (2010), available at http://www.cdc.gov/nchs/data/series/sr_10/sr10_249.pdf.

${ }^{24} I d$.

${ }^{25} I d$. at 6.

${ }^{26}$ Micah Hartman et al., National Health Spending in 2011: Overall Growth Remains Low, but Some Players and Services Show Signs of Acceleration, 32 Health Aff. 87, 88 exh. 1 (2013).

${ }^{27}$ T. Scott Bentley \& STEVen G. Hanson, 2011 U.S. Organ and Tissue Transplant Cost ESTIMATES AND DisCUSSION 3 tbl.1 (2011), available at http://www.publications.milliman.com/research/health-rr/pdfs/2011-us-organ-tissue.pdf.
} 
$2005 .{ }^{28}$ Few Americans can pay for such care out-of-pocket. In 2009, the median household income in the U.S. was $\$ 49,777,{ }^{29}$ and the median net worth was about $\$ 120,000 .^{30}$ More than half the population does not have enough income or assets to pay for this type of care.

The cost is exacerbated by the unpredictability of major illnesses and injuries. ${ }^{31}$ One never really knows when a devastating medical crisis will occur. This makes it difficult, if not impossible, to plan or save for future care. Moreover, when illness strikes, patients have little control over the treatments they receive-and therefore their costs - typically relying on physician recommendations. Thus, patients are often faced with the kind of personal and financial crises that can only be financed by the cost-spreading techniques of insurance.

Of course, insurance is useful for expensive and unpredictable events, such as the loss of one's house in a fire or flood. But, few expensive products are necessities. Food, water, shelter, and clothing are necessities, but they are not unpredictable. Unlike medical care, these necessities are essentially the same for all human beings. The quantity and quality sufficient to sustain survival are predictable. Also unlike medical care, consumers can choose what clothes, housing, and food to buy without professional intervention. These necessities generally are available at affordable prices. To be sure, too many indigent persons are unable to afford healthy food and safe housing without social assistance. Nevertheless, there is no imperative to use insurance to buy food, water, housing, or clothing.

Despite many who consider healthcare to be a commercial good that should be allocated through commercial markets, more Americans treat healthcare like a necessity and a public good. ${ }^{32}$ The public generally responds to an individual in an emergency by providing rescue. ${ }^{33}$ Professional medical ethics has long recognized physicians' responsibilities to help patients in an emergency. ${ }^{34}$ State court decisions have incorporated this ethic into common law, while state and federal legislation has codified it for hospitals with emergency departments, requiring care for emergency medical conditions regardless of ability to pay. ${ }^{35}$ Even though limited to emergencies, this sense of responsibility distinguishes medical care from commercial goods. Medical facilities do not refuse care to anyone whose life could be saved by immediate intervention, whether or not the facilities will be paid for the services they provide. Commercial vendors, however, do not typically provide food, housing, or automobiles to individuals who cannot pay for them.

${ }^{28}$ Zhenxiang Zhao \& Melissa Winget, Economic Burden of Illness of Acute Coronary Syndromes: Medical and Productivity Costs, 11 BMC HeAlth SeRvices Res. 1, 3 (2011).

${ }^{29}$ U.S. Census Bureau, U.S. Dep't of Commerce, Income, Poverty, and Health INSURANCE COVERAGE IN THE UNITED STATES: 2010453 tbl.692 (2011), available at http://www.census.gov/prod/2011pubs/p60-239.pdf.

${ }^{30} \mathrm{Id}$. at 6 tbl.1.

${ }^{31}$ Joseph P. Newhouse et al., Risk Adjustment and Medicare: Taking a Closer Look, 16 HeALTH AFF. 26, 32-33 (1997).

${ }^{32}$ STARR, supra note 2, at 7-10

${ }^{33}$ Paul Slovic, The Feeling of Risk: New Perspectives on Risk Perception 73 (2010); Karen E. Jenni \& George Loewenstein, Explaining the "Identifiable Victim Effect", 14 J. RISK \& UNCERTAINTY 235, 237 (1997).

${ }^{34}$ Code of Medical Ethics $\S 8.11$ Neglect of Patients (Am. Med. Ass'n 1996), available at http://www.ama-assn.org//ama/pub/physician-resources/medical-ethics/code-medicalethics/opinion811.page.

${ }^{35}$ See generally Wilmington Gen. Hosp. v. Manlove, 174 A.2d 135 (Del. 1961); Emergency Medical Treatment \& Active Labor Act (EMTALA), 42 U.S.C. § 1395dd (2012). 


\section{Health Insurance Also Pays for Predictable and Preventive Services}

Health insurance today pays not only for needed medical care that patients cannot foresee, but also for many entirely planned and predictable services. These include preventive services like annual checkups and well-baby examinations, immunizations, mammograms, and similar screening procedures, as well as contraceptive services.

Coverage of preventive services is an anomaly in conventional insurance. Expenses that are likely or certain to occur are not considered insurable risks. ${ }^{36}$ Traditionally, insurance covered only risks that were unforeseeable by the insured, for sensible reasons. ${ }^{37}$ From the insured's perspective, it makes little sense to buy insurance to pay for a service, like an influenza immunization, that the insured already plans to buy. The insurance premium would be more expensive than the price of the immunization alone.

Health insurance coverage of preventive and other planned services resulted from both insurance regulation and market demand. State insurance licensure legislation introduced required coverage of selected preventive services as a matter of social policy. ${ }^{38}$ The purpose of such laws was to encourage people who might not bother or could not afford to get regular preventive examinations to do so in order to avoid more serious (and costly) diseases in the future. ${ }^{39}$ Mandated benefits for preventive services have been a common feature of insurance regulation in most states for many years. ${ }^{40}$

Foreseeable medical care goes beyond prevention; it includes expected treatment for existing medical conditions. A person with diabetes, kidney disease, or hypertension, for example, can expect to need a variety of medical services that would not typically be covered by traditional commercial indemnity insurance. Both state and federal laws later imposed some limits, such as the length of time that insurers could exclude coverage of preexisting conditions. ${ }^{41}$ The ACA eliminates these and other vestiges of traditional insurance. ${ }^{42}$

Even before the ACA became law, health insurance had evolved, sometimes voluntarily, sometimes with a push from government, into a singular species of insurance. The insurance "product" that Chief Justice Roberts described was already dying out. ${ }^{43}$ Health insurance no longer functioned exclusively as a way to spread

${ }^{36}$ See, e.g., Stonehenge Eng'g Corp. v. Emp'rs Ins. of Wausau, 201 F.3d 296, 301-02 (4th Cir. 2000); SCA Serv. Inc., v. Transp. Ins. Co., 646 N.E.2d 394, 397 (Mass. 1995); Steven PlitT ET AL., COUCH ON INSURANCE $\S \S 102.8-102.9$ (3d ed. 2009); JEFFREy W. STEMPEL, STEMPEL ON INSURANCE CONTRACTS 27 (3d ed. 2006).

${ }^{37}$ Mariner, supra note 7 , at 209.

${ }^{38} \mathrm{Id}$.

${ }^{39} \mathrm{Id}$.

${ }^{40}$ See Michael Morrisey, Health Insurance 276 (2007) (noting growth in mandates since the 1970s); Mark Power \& August Ralson, State Mandated Group Health Insurance Coverages, 5 BENEFITS Q. 1, 1-10 (1989) ("The number of state health benefit mandates [has] increased dramatically over the past two decades ... The number of mandates enacted increased from zero in 1965 to approximately 200 by 1975 and then tripled to 604 through $1986 \ldots$. [L] ]egislative interest in state mandated health insurance coverages remains high.”).

${ }^{41}$ See, e.g., Health Insurance Portability and Accountability Act (HIPAA), 29 U.S.C § 1182 (2012).

42 U.S.C. $\S \S 300 \mathrm{gg}-1-13$ (2012).

${ }^{43}$ See NFIB v. Sebelius, 132 S. Ct. 2566, 2591 (2012) ("The Government argues that the individual mandate can be sustained . . . because health insurance is a unique product."). 
the risk of unforeseeable financial loss. It had become the way to pay for healthcare in the United States. ${ }^{44}$

\section{HEALTH INSURANCE AS SOCIAL INSURANCE}

Health insurance has become as necessary as healthcare. ${ }^{45}$ Without health insurance, most Americans could not obtain the healthcare they need, except in emergencies. The ACA was written in recognition of this reality. The goal of making healthcare available to all (or virtually all) could only be financed through modern health insurance methods. Thus, the ACA cemented a broader social function for health insurance, employing it to serve the goal of access to affordable healthcare for all. $^{46}$

In order to enable most Americans to get care, the ACA preserved the financial risk-spreading function of insurance for expensive care, while ending the last traces of risk selection and underwriting that would exclude coverage of beneficial, but predictable, services. ${ }^{47}$ These steps were necessary to make healthcare both affordable and available to almost the entire population, whether used by a government program or by private insurance. ${ }^{48}$

The ACA fills the gaps in the fragmented array of public and private health insurance programs and links them together into a social insurance system. As Rashi Fein has stated, the ACA is an overall program that is "compulsory for the population group covered, contributory, and earmarked, with contributions that are not adjusted for risk and therefore are redistributive." ${ }^{, 49}$ In this system, private health insurance serves a function similar to that of worker compensation insurance, unemployment insurance, Social Security, and Medicare; that is to say, it ensures that those in need of assistance have access to a source of funding for that aid. ${ }^{50}$

${ }^{44}$ David Goldhill, CATASTROPhic CARE 30 (2013).

45 See Inst. of Med., America's Uninsured Crisis: Consequences for Health and HEALTH CARE 49 (2009), available at http://www.nap.edu/catalog.php?record_id=12511 ("For people without health insurance, there is a chasm between health care needs and access to needed services despite the availability of some safety net services. With health insurance, children are more likely to gain access to a medical home, well-child care and immunizations, prescription medications, appropriate care for asthma, and basic dental services. They are also more likely to have fewer avoidable hospitalizations, improved asthma outcomes, and fewer missed days of school. Uninsured adults face serious and sometime [sic] grave risk to their health. Without health insurance, adults have less access to effective clinical services including preventive care and, if sick or injured, are more likely to suffer poorer health outcomes, greater limitations in quality of life, and premature death. When adults gain health insurance, they experience improved access to effective clinical services and better health outcomes.").

${ }^{46}$ STARR, supra note 2, at 241. Care for "all," of course, remains something of an overstatement, since twenty-three states, as of this writing, have declined to participate in the Medicaid expansion. Moreover, the ACA does not require undocumented aliens to have insurance coverage. KAISER

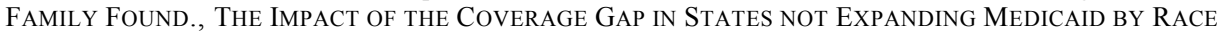
AND ETHNICITY 2 (2013), available at http://kaiserfamilyfoundation.files.wordpress.com/2013/12/8527-the-impact-of-the-coverage-gap-instates-not-expanding-medicaid.pdf.

${ }^{47}$ See STARR, supra note 2, at 240-41.

${ }^{48}$ See generally Jacob S. Hacker, The Divided Welfare State: The Battle over Public AND PRivate Social Benefits in the United States 3 (2002).

${ }^{49}$ Rashi Fein, Advancing a Single-Payer System of Social Insurance, in Social Welfare Policy at the Crossroads: Rethinking the Roles of Social Insurance, Tax EXPenditures, Mandates, AND MEANS-TEsting 87, 87 (Robert B. Frieland et al. eds., 1994).

${ }^{50}$ See Roy Lubove, The Struggle for Social Security 3 (1970) ("Social insurance was proposed as an alternative to the existing, but inefficient, system of economic assistance. Operating independently of the poor laws, it would respond predictably and adequately in the event of an 
Tom Baker and Deborah Stone have noted that risks covered by insurance are often viewed as risks that should be shared by a community. ${ }^{51}$ Richard Ericson and colleagues explain that insurance is "a moral technology" in the sense that it "defines how people should act." "J2 Jeffrey Stempel has described the insurance policy itself as a social institution, "often acting as adjunct arms of governance and reflecting social and commercial norms." ${ }^{, 53}$ As more people are able to obtain health insurance, whether public or private, the idea of having health insurance becomes routine and expected. Because insurance is a means of spreading costs, the expectation of health insurance suggests that the cost of healthcare is a shared responsibility - at least to the extent of the benefits it covers. ${ }^{54}$

In the most fundamental sense, Chief Justice Roberts was correct to characterize the ACA's individual mandate as a tax. ${ }^{55}$ Premiums paid for social insurance function much like taxes. As Henry Aaron noted, the payroll taxes that fund Social Security and Medicare are analogous to insurance premiums, except that the payroll taxes are more regressive than income taxes, because they are the same percentage of income, up to a cap, for everyone. ${ }^{56}$

In a 1927 Supreme Court case concerning taxes on insurance premiums, Justice Oliver Wendell Holmes famously wrote in a dissenting opinion, "[t]axes are what we pay for civilized society, including the chance to insure. ${ }^{, 57}$ In Justice Holmes's view, the premium tax is a paid for the social and economic protections provided by the state, including the opportunity to conduct business in a fair and secure environment. Today's insurance premiums are analogous to such taxes. Even when paid to private industry, they finance the care needed to live and work in society.

\section{IMPLICATIONS FOR HEALTH INSURANCE}

Why should it matter that health insurance has become the primary method of paying for healthcare and a form of social insurance? There are at least two reasons. First, the shift challenges the conventional conception of insurance as a voluntary, commercial relationship between insurer and insured, but it does not necessarily offer universally acceptable, normative standards on how insurance law should respond to this "new" relationship. This injects some new uncertainties into an area of law already beset by competing conceptions of the role of insurance in general. Second, recognizing health insurance as a payment system should focus more attention on the kinds of care that should be available to everyone. If health insurance is to function as a form of social insurance, who decides what coverage is

individual's exposure to the long- and short-term risks which interrupted income flow: accident, sickness and maternity, old age and invalidity, unemployment, or death resulting in impoverished dependency.").

${ }^{51}$ TOM BAKER, EMBRACING RISK 27 (Tom Baker \& Jonathan Simon eds., 2002); Deborah Stone, Beyond Moral Hazard: Insurance as Moral Opportunity, 6 ConN. InS. L.J. 11, 46 (1999).

${ }^{52}$ RichaRd V. ERICSON ET AL., INSURANCE AS GOVERNANCE 10 (2003).

${ }^{53}$ Jeffrey W. Stempel, The Insurance Policy as Social Instrument and Social Institution, 51 WM. \& MARY L. REV. 1489, 1495 (2010).

${ }^{54}$ See Michael J. Graetz \& Jerry L. Mashaw, True Security: Rethinking American SOCIAL INSURANCE 167-71 (1999).

${ }^{55}$ See NFIB v. Sebelius, 132 S. Ct. 2566, 2608 (2012).

${ }^{56}$ Henry J. Aaron, Mandated Benefits with a Social Insurance Option, in Social Welfare POLICY AT THE CrossRoAdS 87, 87 (Robert B. Frieland et al. eds., 1994).

${ }^{57}$ Compania Gen. De Tabacos De Filipinas v. Collector of Internal Revenue, 275 U.S. 87, 100 (1927) (Holmes, J., dissenting). 
essential? Government regulation and private market contracting are likely to offer different, albeit also incomplete, answers. Each of these is discussed below.

\section{A. A Social Insurance Conception of Health Insurance}

The ACA's social insurance conception of health insurance partially straddles four conceptions of insurance delineated by Kenneth Abraham. ${ }^{58}$ The "contract conception" is what Abraham calls the "traditional and dominant conception of insurance . . . as a contract transferring risk of loss to a party whose business is selling such contracts, rather than as an incident of another transaction." ${ }^{59}$ The "product conception" views the insurance policy more like a commodity than a contract; the product could be found defective under rules, like products liability, defining the validity of contract terms, rather than generally deferring to the text of standard form contracts used in insurance to define rights and obligations. ${ }^{60}$ The "public utility/regulated industry conception" views insurance much like a natural monopoly, such as the water or electricity markets, which are highly regulated "in order to serve the public interest." by Richard V. Ericson and colleagues, ${ }^{62}$ describes how insurance functions much like (and can serve as a substitute for) a government to the extent that it influences the behavior of those insured to prevent or mitigate risks. ${ }^{63}$

Elements of each of these conceptions of insurance are discernable in the ACA, but none wholly encompasses the overall function of the healthcare financing methods that the ACA contemplates. Of course, Abraham's analysis focuses on private insurance, whereas health insurance-pre- and post-ACA - includes both private plans and public programs. To be sure, the ACA intensifies regulation of private, commercial health insurers and their policies. Abraham notes that health insurance is the insurance field most closely aligned with the public utility conception. ${ }^{64}$ But he concludes that it is not a complete match, because, unlike public utilities, which charge consumers according to their use of the service, health insurance under the ACA redistributes risk. ${ }^{65}$ Medicare, Medicaid, and the Veterans Affairs health benefits programs might also share some similarities with public utilities, but they are more properly viewed as government benefit or entitlement programs - redistributive tax and transfer programs - and not regulated industries.

In a social insurance system, a health plan is a means rather than an end-a method of financing expected costs, rather than a commercial contract or product to

${ }^{58}$ Abraham, supra note 21, at 657.

${ }^{59} I d$. at 658 . A key focus of the contract conception is the degree to which the contract's text governs the specific losses for which the insurer will pay, as well as the rules for interpreting that text.

${ }^{60} \mathrm{Id}$. at $674-75$. For a discussion of the product conception, see generally Jeffrey W. Stempel, The Insurance Policy as Thing, 44 TORT TRIAL \& INS. PraC. L.J. 813 (2009); Daniel Schwarcz, A Products Liability Theory for the Judicial Regulation of Insurance Policies, 48 WM. \& MARY L. REV. 1389 (2007).

${ }^{61}$ Abraham, supra note 21, at 668 .

${ }^{62}$ ERICSON ET AL., supra note 52, at 53; see also Stempel, supra note 53, at 1495.

${ }^{63}$ Abraham, supra note 21, at 683-84.

${ }^{64} \mathrm{Id}$. at 670 . Given the redistribution of former monopolies, such as telephone services, into competing private companies, the traditional public utility model that Abraham describes applies to a narrower set of industries today. Companies offering competing landline and mobile telephone, cable, or wireless internet services, for example, might offer a modified model of public utilities, with somewhat less regulation, especially with respect to pricing, than traditional public utilities.

${ }^{65} \mathrm{Id}$. at 672 . 
reimburse stipulated losses. Under the ACA, redistribution of risk - or the costs of healthcare - is a central goal, which is characteristic of social insurance. Thus, legislation and regulations are likely to dominate health policy decision-making in order to ensure that private health insurance plans serve the ACA's goals. This contrasts with the contract conception of an entirely private market, where contracts are the predominant regulator of commercial relationships, rights and duties. Most commercial health insurance policies are ordinary consumer products that are sold in the market to voluntary purchasers on the basis of ability to pay, on the seller's terms and conditions embodied in standard form contracts, with minimal regard to individual consumer needs. ${ }^{66}$ As discussed below, the contract conception remains alive and well within the ACA's framework, because contracts will continue to specify many details of the insurer-insured relationship, including entitlement to specific treatments. ${ }^{67}$ Nonetheless, when insurance is used to finance a goal like access to healthcare, the insurance contract or "product" itself must be designed to achieve that goal, instead of other goals the insurer may prefer.

In the public financing systems, like Medicare and healthcare for military personnel and soldiers, legislation specifies the legal and policy framework for an entire program, with administrative rules filling in the details. When multiple private insurers are used to finance healthcare, more complex regulation is needed to ensure that private entities, working independently, offer insurance plans that are designed to achieve the public goal of financing healthcare. ${ }^{68}$ The more a financing system relies on the private sector, the more regulation of private entities will be required to achieve the overall goal. This means that legislation and regulations will increasingly shape the boundaries of health insurance coverage and pricing.

The ACA continues to rely on the states to license and regulate insurers and their policies, but it also imposes new federal requirements. Insurance commissioners now need to regulate according to federal as well as state law. This includes evaluating the actuarial value of qualified health plans to be sold on health insurance exchanges, ${ }^{69}$ as well as medical loss ratios, risk corridors, ${ }^{70}$ and risk adjustments. ${ }^{71}$ State regulators also are to work with the Secretary to develop uniform explanations of health plans for consumers ${ }^{72}$ and reporting requirements for insurers. ${ }^{73}$ Although federal funding is available to build up state regulatory capacity to review premium increases ${ }^{74}$ many states are likely to remain underfinanced for the increased level of scrutiny their insurance commissioners are expected to provide. ${ }^{75}$ Some insurance departments barely have enough staff members to make

\footnotetext{
${ }^{66} \mathrm{Id}$. at $658,674-75$.

${ }^{67}$ See discussion infra Part IV.B.2.

${ }^{68}$ See, e.g., Timothy Jost, Nat'l Acad. of Soc. Ins., The Regulation of Private Health INSURANCE 29-31 (2009), available at http://www.nasi.org/usr_doc/The_Regulation_of_Private_Health_Insurance.pdf (describing the increased frequency of regulatory interventions needed to address market failures in U.S. private health insurance that do not appear in a single payer system).

${ }^{69} 42$ U.S.C. $\$ 18022(d)(2)(2012)$.

${ }^{70} I d . \S 18062(\mathrm{a})$.

${ }^{71} I d . \S \S 18022(\mathrm{c})(4), 18063$. Beyond qualified plans, insurance regulators remain responsible for catastrophic plans, $i d$. $\S 18022(\mathrm{e})$, child-only plans, $i d$. $\S 18022(\mathrm{f})$, separate plans for dental and mental health services, grandfathered plans sold to large employers and other non-qualified plans.

${ }^{72} \mathrm{Id} . \S 300 \mathrm{gg}-15$.

${ }^{73} \mathrm{Id} . \S 300 \mathrm{gg}-17$.

${ }^{74} \mathrm{Id}$. § 300gg-94(c).

${ }^{75}$ See Kenneth S. Abraham, Insurance Law and Regulation 142 (5th ed. 2010) (describing the variation in resources available to insurance commissioners in different states).
} 
sure that insurers are financially solvent, much less to review each policy for its actuarial soundness and compliance with pre-ACA consumer protection rules. ${ }^{76}$ Now, they must also determine whether the policies offered on health insurance exchanges comply with all the federal rules. ${ }^{77}$

State insurance departments may also need to review and approve insurers' participation agreements with providers, since these agreements may be key to ensuring that premiums are adequate to cover expected outlays. ${ }^{78}$ Moreover, if consumers are supposed to choose health plans wisely, they may need to know how an insurer pays its providers and perhaps even how providers pay themselves. ${ }^{79}$ This requires more transparency than is currently provided. ${ }^{80}$ Payments to providers are likely to be the primary target for cost control. There is little dispute that such payments have grown faster than the cost of living or that provider prices often appear arbitrary. ${ }^{81}$ The ACA authorizes experiments to encourage providers to work together to provide care more efficiently at lower prices in accountable care organizations and other arrangements, but providers still have little incentive to reduce their own incomes without pressure from insurers. ${ }^{82}$ The degree to which

${ }^{76}$ See id. at 142 (emphasizing the constrained budgets and staffing conditions in insurance departments).

7742 U.S.C. § 18021. To see how complicated this might become, consider the Final Rules under the Paul Wellstone and Pete Domenici Mental Health Parity and Addiction Equity Act of 2008. See generally External Review for Multi-State Plan Program, 78 Fed. Reg. 68,240 (Nov. 13, 2013) (to be codified in scattered sections of 26 and 45 C.F.R.). Health insurers have typically carved out mental health benefits and subcontracted with a separate insurer or organization that made coverage (and medical necessity) determinations largely independently, or at least their criteria were not necessarily applied in the same way as how the primary insurer applied its own coverage criteria for medical care. Primary insurers may have to do some complex mapping of coverage, deductibles, co-pays, participating providers, and numbers of visits to establish parity. Insurance commissioners may have to review and approve such parity estimates.

${ }^{78}$ Providers are aware of the external pressure to keep their prices low, but are consolidating in order to gain bargaining power. Most estimates say that consolidation typically yields a three percent increase in prices. Health Care Industry Consolidation: Hearing Before the Comm. on Ways \& Means Subcomm. on Health, 112th Cong. 13-18 (2011) (statement of Martin Gaynor, E.J. Baron Professor of Economics and Health Policy, Heinz College, Carnegie Mellon University) (noting that in different geographic markets, hospital mergers have been shown to increase prices by anywhere from five percent to over fifty percent).

${ }^{79}$ For a thoughtful study of the information consumers need to choose insurance plans, see Erik J. Johnson et al., Can Consumers Make Affordable Care Affordable? The Value of Choice Architecture, 8 PLOS ONE 1 (2013).

${ }^{80}$ Most insurers keep their provider payment systems proprietary. Even government employers often sign nondisclosure agreements if they receive information from insurers as well as third party administrators and management consultants; were it not for these nondisclosure agreements, provider payment data could be subject to FOIA requests.

${ }^{81}$ Steven Brill, Why Medical Bills Are Killing Us, Time, Feb. 20, 2013, at 1, 16-55.

${ }^{82}$ Medicare's governing legislation requires CMS to set physician payment rates annually. Social Security Act $\S 1848(d)$. The statutory formula for Sustainable Growth Rates (SGR) has required reductions in payment rates since 2002, but Congress has postponed enforcement of those reductions annually. Were the cumulative reductions to take effect in 2014, Medicare payments to physicians would decline by about twenty-four percent. Letter from Jonathan D. Blum, Principal Deputy Administrator, Ctrs. For Medicare \& Medicaid Servs., to Glenn M. Hackbarth, Chair, Medicare Payment Advisory Comm'n (Mar. 11, 2014), available at http://www.cms.gov/Medicare/MedicareFee-for-Service-Payment/SustainableGRatesConFact/downloads/medpacfinal.pdf; Sustainable Growth Rates and Conversion Factors, Ctrs. For Medicare \& Medicaid Servs. (last modified Apr. 15, 2014), http://www.cms.gov/Medicare/Medicare-Fee-for-Service-Payment/SustainableGRatesConFact/ index.html?redirect=/sustainablegratesconfact/01_overview.asp. Some of the estimated federal savings expected from ACA reforms were based on the assumption that Medicare would reduce its costs by implementing the SGR. Recently, legislators began to consider whether to replace the fee for service physician payment structure with methods that reward quality and cost saving, like the 
such organizations accept the financial risk of providing care raises additional questions for insurance regulation. ${ }^{83}$ States may have to decide whether to regulate providers who accept risk (through an accountable care organization, for example) as insurers or impose alternative requirements to ensure their financial soundness. ${ }^{84}$

\section{B. Who Decides What Coverage Is OfFered AND PaID For?}

A threshold question for any social insurance system is what coverage must be offered. While the ACA intends to provide more uniform coverage through its requirement for Essential Health Benefits (EHB) ${ }^{85}$ the decisions most important to patients - what treatment their own insurance will pay for when they get sick - turn out to be more complex under the ACA's financing structure than under a national, public social insurance system.

What qualifies as essential care is a question that has vexed policy makers for decades. ${ }^{86}$ A threshold question is: essential for whom? An individual's view of what is essential care may differ from a societal perspective. Moreover, different individuals may have different opinions on what is essential. Some may value quality of life more than length of life, while others prefer the opposite. ${ }^{87}$ Some may prefer care that maintains or restores normal function, while others simply want to survive, regardless of disability. ${ }^{88}$ Some may think of healthcare as limited only to services that diagnose, treat or cure disease, while others may include services to prevent illness or even achieve optimal health status. Furthermore, an individual's own preference may vary, depending upon whether she acts as a consumer buying insurance or a patient in need of care for herself or a loved one. ${ }^{89}$

bundled payments used for hospital services or global payments for accountable care organizations. Gail R. Wilenksy, Improving Value in Medicare with an SGR Fix, 370 New EnGL. J. MED. 1 (2014). For Medicare programs, see Innovation Models, Ctrs. For Medicare \& MedicAid Servs., http://innovation.cms.gov/initiatives/index.html\#views=models (last visited May 8,2014). Agreements between CMS and provider ACOs under the Medicare Shared Savings Program allow the provider organization to share savings (reductions in the amount of Medicare payments to the ACO from payment amounts in an earlier benchmark period) without subjecting ACOs to risk for financial losses from providing care. Patient Protection \& Affordable Care Act § 3022, 42 U.S.C. § 1395jjj (2012). Regulations and Guidance on the Medicare Shared Savings Program may be found at http://www.cms.gov/Medicare/Medicare-Fee-for-Service-Payment/sharedsavingsprogram/Statutes Regulations_Guidance.html. CMS may consider adding shared risk in its new Innovation Program; see 42 U.S.C. $\S 1315$ a. CMS issued a Request for Information seeking suggestions by March 1, 2014, for new ACO models that encourage greater care integration and financial accountability. CTRS. FOR Medicare \& Medicaid Servis., Ctr. for Medicare \& Medicaid Innovation, Request for INFORMATION: EVOLUTION OF ACO INITIATIVES AT CMS 1 (2014), available at http://innovation.cms.gov/Files/x/Pioneer-RFI.pdf.

${ }^{83}$ For a discussion of earlier experiences with regulating risk-bearing providers, see Allison Overbay \& Mark A. Hall, Insurance Regulation of Providers that Bear Risk, 22 AM. J.L. \& MED. 361 passim (1996).

${ }^{84}$ For one state's proposal to impose tiered levels of financial requirements on providers who accept varying levels of risk, see 1251 Mass. Reg. 20 (Jan. 3, 2014).

${ }^{85} 42$ U.S.C. $\$ 18022$ (2012). See Part IV.B.1, infra.

${ }^{86}$ See generally Daniel Callahan, What Kind of Life: The Limits of Medical Progress (1990); Norman Daniels, Just Health Care (1985); Victor R. Fuchs, Who Shall Live? Health, Economics, and Social Choice (1974); Edmond D. Pelligrino \& David C. Thomasma, For the Patient's Good: The Restoration of Beneficence in Health Care (1988).

${ }^{87}$ See CALLAHAN, supra note 86 , at 18-20.

${ }^{88}$ See DANIELS, supra note 86 , at 2-5.

${ }^{89}$ Wendy K. Mariner, Standards of Care and Standard Form Contracts: Distinguishing Patient Rights and Consumer Rights in Managed Care, 15 J. CONTEMP. Health L. \& POL'Y 1, 12-18 (1998). 
Societal level views of essential care also vary. Indeed, one could question whether some societies accurately or adequately represent any consensus on the part of their populations. Where governments act honestly, essential care could properly be based on many different factors, such as population size, age distribution, and available resources. What is essential to any society may also depend on its need for economic growth, which may favor services that preserve productivity, or participation in civic life, which may favor other services, or some other human function. But, given the variation in individual preferences in a population as diverse as that of the United States, any societal level choice, no matter how thoughtfully produced, may conflict in whole or in part with the views of individuals or groups within the population.

\section{Essential Health Benefits under the ACA}

Majority rule may - or may not - be the appropriate normative standard to determine essential care at the more abstract level of general categories of coverage. The ACA appears to assume that it is by requiring private insurers to cover EHB in all plans that they offer to sell on a health insurance exchange or in the individual and small group market (but excluding grandfathered plans of large employers). ${ }^{90}$ EHB must be similar in scope to a "typical employer plan" and must include the following ten categories of medical services: ambulatory; emergency; inpatient hospitalization; maternity and newborn; mental health and substance abuse; prescription drugs; rehabilitation; laboratory; preventive; and pediatric (including dental and vision care). ${ }^{91}$ The Federal Secretary of Health and Human Services is charged with defining EHB, and is required to take the following specific "considerations" into account: the categories must be balanced, without giving undue weight to any one category; coverage should not discriminate on the basis of age, disability, or expected length of life; EHB should take into account the needs of diverse groups, including women, children, and people with disabilities; benefits should not be denied on the basis of age, expected length of life, present or predicted disability, degree of medical dependency, or quality of life. ${ }^{92}$

This general definition of EHB is quite comprehensive, and the "considerations" make it difficult to narrow the categories or to make decisions about how they might apply to individual patients. ${ }^{93}$ So far, this rather vague and flexible definition of EHBs is based on state choices of typical small employer plan coverage-in effect, trickling up from insurers. ${ }^{94}$ But it does represent a step toward developing

${ }^{90} 42$ U.S.C. $\S \S 18021-18022$ (2012).

${ }^{91} I d . \S 18022(\mathrm{~b})(1)$.

${ }^{92}$ Id. $\S 18022(\mathrm{~b})(4)$.

${ }^{93}$ Not surprisingly, the Secretary avoided listing specific benefits, instead issuing a rule granting the states the opportunity to decide what benefits plans will cover in their states. Essential Health Benefits, Actuarial Value, and Accreditation, 78 Fed. Reg. 12,833-12,872 (Feb. 25, 2013) (to be codified at 45 C.F.R. pts. 147, 155-56). A state may choose one of several existing health plans sold to small employers in that state (called a "benchmark plan"), and the benefits covered by that plan will be deemed to qualify as EHB. The benchmark plan, however, must be supplemented if it fails to cover any of the 10 required categories. $I d$.

${ }^{94}$ See id. While ACA states that Essential Health Benefits should be similar in scope to the benefits covered by a "typical employer plan," it does not distinguish between large employer plans and small employer plans. Small employer plans typically offer fewer benefits and more limited coverage of those benefits than large employer plans in order to keep premiums affordable. Thus, a typical small employer plan usually has a lower actuarial value than a large employer plan. To counter rising premiums, companies have increased the amounts that employees pay for health plans - both the employee's share of premiums and deductibles and co-payments for receiving care. See Steven 
consensus on the basic types of care that should be available to all. The benefits covered by large employee group plans are already similar. Greater consensus on essential coverage may emerge in the future, ideally with public input, and national standards may begin to trickle down from the state or federal government to insurers. Experiments with Medicare and Medicaid coverage and provider payment methods also may begin to incorporate the same or similar conception of essential health benefits, so that benefit packages in both public and private health plans may converge more closely than in the past. ${ }^{95}$ Of course, supplementary private insurance and personal funds will undoubtedly remain available to pay for elective and boutique services. Nonetheless, similar public and private benefit packages would reinforce consensus on what counts as care to which everyone should have access.

Similar coverage across many plans facilitates comparisons for consumers. In theory, consumers need only compare prices for the same set of benefits. In health insurance, however, a plan's participating providers are also a major factor in consumers' choice of health plans, even if often secondary to price.

\section{Coverage and Treatment Decisions - Contracts Again}

Paradoxically, variation in EHB definitions can perpetuate a problem that the EHB requirement itself was intended to resolve or at least reduce-inconsistent or inadequate treatment coverage. Historically, the fact that different insurers covered different benefits meant that people with the same medical condition would not necessarily receive the same treatment. ${ }^{96}$ The remaining variation among the several public benefit programs and hundreds of private insurance plans can provoke complaints of unfair rationing, especially if a person who is denied treatment believes that the denial was not based on medical need, but on an insurer's profit targets. ${ }^{97}$ More uniform coverage of the same benefits could avoid the rationing charge by assuring that everyone is subject to the same rules. The knowledge that resources are being used for a public purpose, such as providing needed education or

Blakely, Employers, Workers, and the Future of Employment-Based Health Benefits, 330 EMP. BENEFIT RES. INST. 4 (2010). The ACA, however, limits out-of-pocket co-payments. 42 U.S.C. § 18022(c)(2). Moreover, a small employer may have few affordable choices, so its plan may not cover the benefits that employees prefer. However, since the majority of people who will be entering the market are individuals and employees of small businesses, it may make sense to use a small employer plan as a benchmark.

${ }^{95}$ See, e.g., Additional Information on Proposed State Essential Health Benefits Benchmark Plans, Ctrs. FOR MEdiCARE \& MediCAID SERVs., http://www.cms.gov/CCIIO/Resources/DataResources/ehb.html (last visited Apr. 9, 2014); Michelle Lilienfeld, Overview of HHS' Proposed Rule on Benefits for the Medicaid Expansion Population: A Step Guide for Advocates, NAT'L HEALth LAW PROGRAM (Apr. 1, 2013), http://www.healthlaw.org/issues/medicaid/health-reform-andmedicaid/overview-of-hhs-proposed-rule-on-benefits-for-the-medicaid-expansion-population-a-steguideffor-advocates\#.UymmYqDIpLE (discussing Medicaid Alternative Benefit Plans, which starting in 2014 are required to either meet all ten EHB benefit categories or be supplemented to make them comparable to a relevant EHB-based benchmark plan).

${ }^{96}$ See Amanda Cassidy, Essential Health Benefits, Health Aff., Health Pol’y Brief 1-2 (May 2, 2013),. http://healthaffairs.org/healthpolicybriefs/brief_pdfs/healthpolicybrief_91.pdf (noting the historical absence of a uniform national standard for health insurance benefits and discussing the vast differences in coverage among plans before the Affordable Care Act required coverage of essential health benefits).

${ }^{97}$ See Normal Daniels, Why Saying No to Patients In The United States Is So Hard - Cost Containment, Justice and Provider Autonomy, 314 New Eng. J. MED. 1380, 1383 (1986) (noting that patients are distrustful of health care schemes that make a profit through denial of care); Wendy K. Mariner, Rationing Health Care and the Need for Credible Scarcity, 85 AM. J. PuB. Health 1439, 1442 (1995) ("[Patients] may fear they are being denied care so that the money can be used to profit the organization."). 
services for children, can increase public acceptance of limits as a shared sacrifice. On one hand, the breadth of the statutory definition of EHB will make it difficult to limit the total package of benefits. On the other hand, the Secretary's decision to use state-based benchmark plans to define EHB means that the details of each benefit category will continue to vary, so that individuals might still complain of unfair treatment, thereby threatening public acceptance.

While the ACA intends to provide more uniform coverage of EHBs, the process of determining what kinds of care patients receive may not dramatically change for the foreseeable future. Most insurance plans and benefit programs necessarily define covered benefits in quite general terms much like the statutory definition of EHB. Given the breadth of required coverage, the decisions most important to patients - exactly what treatment will and will not be paid for within the general categories-remain with the insurer.

Because the United States has so many different insurance plans, both the decision maker and the law governing the determination of claims for treatment vary. Federal government programs like Medicare prescribe general benefit categories in legislation, but specific determinations on whether and when specific items and services are covered are a matter of administrative law. ${ }^{98}$ The Department of Health and Human Services, Centers for Medicare and Medicaid (CMS) issues regulations and guidance interpreting the statute and describing what will and will not be paid for. ${ }^{99}$ However, the federal agency does not make decisions about individual patient care ${ }^{100}$ Instead, CMS contracts with private contractors to do so on its behalf. ${ }^{101}$ Typically, these contractors are insurance companies, which have experience handling claims, usually because they have a separate private insurance business of their own. ${ }^{102}$ Different contractors handle claims in different regions of the country, so it is possible to have inconsistency in claims determination. In the case of disputes, patients have a statutory right to appeal the denial of payment to Medicare's administrative appeals process, which is a unified federal system with greater consistency in results. ${ }^{103}$

${ }^{98}$ See Barbara S. Klees et al., Brief Summaries of MedicAre ANd MedicAid, CTRS. For MEDICARE \& MEDICAID SERVs. 22 (2012), available at https://www.cms.gov/Research-StatisticsData-and-Systems/Statistics-Trends-and-

Reports/MedicareProgramRatesStats/Downloads/MedicareMedicaidSummaries2012.pdf (stating that federal authority to administer the Medicare and Medicaid systems has been delegated to, at various times, the Department of Health and Human Services, the Social Security Administration, the Social and Rehabilitation Service, and the Centers for Medicare \& Medicaid Services).

${ }^{99}$ See id. at 18 (organizations and agencies acting on behalf of the federal government apply Medicare coverage rules to determine appropriate payments); Rulings, CTRS. FOR MEDICARE \& MEDICAID SERVS., http://www.cms.gov/Regulations-and-Guidance/Guidance/Rulings/index.html (last modified Feb. 27, 2012, 2:24 PM)

${ }^{100}$ See Kathleen M. King \& James Cosgrove, Medicare: Contractors and Private Plans Play a Major Role in Administering Benefits, Gov'T. ACCOUNTABILITY OfFICE 2-3 (Mar. 4, 2014), available at http://www.gao.gov/assets/670/661317.pdf (providing overview of how CMS contracts with Medicare Administrative Contractors and private organizations to provide various services); Klees et al., supra note 98, at 18 (discussing the role of contractors in determining which services are covered).

${ }^{101}$ See 42 C.F.R. $\$ 405.920$ (2013); Klees et al., supra note 98, at 18 (discussing fiscal intermediaries, which are organizations or agencies that contract with the federal government to process Medicare claims).

${ }^{102}$ See King \& Cosgrove, supra note 100, at 2 (explaining that the Medicare fee-for-service program "was designed so that the federal government contracted with health insurers or similar private organizations experienced in handling physician and hospital claims to process and pay Medicare claims rather than having the federal government do so").

${ }^{103} 42$ C.F.R. $\S 405.904$ 
Medicaid programs offer somewhat less consistency. Although Medicaid is a federal program with legislatively prescribed benefit categories, the states administer the program and can voluntarily, or with a federal waiver, cover additional or alternative benefits. ${ }^{104}$ Most state Medicaid programs make individual patient care determinations directly through a state Medicaid administrative agency. ${ }^{105}$ However, most states also contract with private insurers to enroll some Medicaid beneficiaries in a managed care plan. ${ }^{106}$ The insurer makes the initial benefit coverage determination for beneficiaries enrolled in its Medicaid plan. ${ }^{107}$ Disputes, however, are subject to a state's administrative agency review, often with a dedicated appeals board. $^{108}$

Contract law governs individual benefit determinations for patients who are enrolled in private insurance plans. Despite drawing on many of the same common law principles, the judiciary in different states can apply somewhat different substantive and procedural rules with varying results. Claims determination often depends on specific contract provisions, especially those that exclude experimental procedures and those that limit coverage to treatments that are medically necessary for the individual patient. ${ }^{109}$ Here, decision-making is likely to continue to operate under a contract conception of insurance. That conception, however, does not necessarily produce consistent treatment determinations for patients in the same or similar circumstances. Indeed, doctrinal disputes that often occur in the context of all types of insurance policies will undoubtedly continue to arise with respect to claims determinations under health plans: the degree to which an insurance contract should be treated as a contract of adhesion, ${ }^{110}$ application of contra proferentem to construe ambiguous contract terms against the insurer as drafter, ${ }^{111}$ whether the parties are bound by the text of contract provisions or the reasonable expectations of the insured, ${ }^{112}$ the scope of subrogation clauses and whether state subrogation laws

${ }^{104}$ See Klees et al., supra note 98, at 22 ("Within broad national guidelines established by Federal statutes, regulations, and policies, each State establishes its own eligibility standards; determines the type, amount, duration, and scope of services; sets the rate of payment for services; and administers its own program.”).

105 Medicaid Administrative Claiming, MediCAID.gOv, http://www.medicaid.gov/MedicaidCHIP-Program-Information/By-Topics/Financing-and-Reimbursement/Medicaid-AdministrativeClaiming.html (last visited Apr. 9, 2014).

${ }_{106}$ See id.; Klees et al., supra note 98, at 29; Managed Care, Medicaid.gov, http://www.medicaid.gov/Medicaid-CHIP-Program-Information/By-Topics/Delivery-

Systems/Managed-Care/Managed-Care.html (last visited Mar. 25, 2014) (discussing trends in Medicaid, noting the growth of State-designed Medicaid managed care programs); Financing \& Reimbursement, MEDICAID.GOv, http://www.medicaid.gov/Medicaid-CHIP-Program-Information/ByTopics/Financing-and-Reimbursement/Financing-and-Reimbursement.html (last visited Mar. 25, 2014) (noting that approximately seventy percent of Medicaid enrollees get care through a managed care delivery system).

${ }^{107} 42$ C.F.R. $\S 405.920$

${ }^{108} I d . \S 405.908$.

${ }^{109}$ See, e.g., Loyola Univ. of Chi. v. Humana Ins. Co., 996 F.2d 895, 897-901 (7th Cir. 1993) (analyzing whether a transplant was covered where the contract excludes procedures that do not meet the criteria for "medical necessity" and procedures that are "experimental" for the condition).

${ }^{110}$ The classic analysis of contracts of adhesion is found in Friedrich Kessler, Contracts of Adhesion-Some Thoughts about Freedom of Contract, 43 Colum. L. REV. 629 passim (1943).

${ }^{111}$ See Robert E. KeEton \& Alan I. Widiss, InSurance LAW § 6.3(a) (1988).

${ }^{112} \mathrm{Id}$. 
are preempted by Employee Retirement Income Security Act (ERISA), ${ }^{113}$ and the requirements for an insurer's defense to a claim of bad faith. ${ }^{114}$

Most private insurers provide internal review (conducted by the insurer itself) of enrollee complaints, including disputes over benefit denials, and the ACA requires almost all insurers to offer a more transparent internal appeal process covering more categories of complaints. ${ }^{115}$ Enrollees who are dissatisfied with the internal review decision have very different options, depending on their particular insurer and plan. In theory, patients can sue a private insurer under state law for claims denials and other causes of action. ${ }^{116}$ However, the role of courts in determining claims has diminished somewhat in the past decade, for several reasons. Perhaps the most important has been the growing prevalence of mandatory arbitration clauses in private insurance contracts, which preclude an enrollee from bringing a lawsuit to require payment for treatment or to recover damages for negligence or other violations of law. ${ }^{117}$ The United States Supreme Court has also limited the causes of action available to patients who are enrolled in an employer's group health plan. ${ }^{118}$ Patients in such plans who claim wrongful denial of benefits must sue the employer's plan under the federal Employee Retirement Income Security Act, not state law. ${ }^{119}$ If successful, the patients are entitled to recover only the cost of the treatment denied and not any damages for personal injury. ${ }^{120}$

A third reason for fewer court actions is the growth of external review systems. Almost all states now require insurers to submit certain disputes to a review panel that is entirely independent of the insurer. ${ }^{121}$ Having one's claim reviewed by an unbiased expert or group of experts often satisfies patients that their claims have been evaluated fairly, regardless of the outcome. ${ }^{122}$ The ACA greatly expands the use of external review panels, requiring their use for almost all insurers, except certain employer-sponsored group health plans. ${ }^{123}$

The ACA leaves in place a multiplicity of processes and decision-makers for determining individual claims, including public administrative procedures, private review procedures, private arbitration, and judicial process. ${ }^{124}$ The Act does not specify how decisions are made in individual cases. With rising healthcare costs, both public and private insurers are likely to face pressure to make sure that they pay

\footnotetext{
${ }^{113}$ See, e.g., U.S. Airways, Inc. v. McCutchen, 133 S. Ct. 1537 (2013).

${ }^{114}$ See, e.g., Bjornstad v. Senior Am. Life Ins. Co., 599 F. Supp. 2d 1165, 1174 (D. Ariz. 2009) (allowing plaintiffs to bring a claim of bad faith against administrator of home health care insurance policy for offering conflicting bases for denying coverage of services rendered after patient's health condition required transfer out of the home and into a nursing facility); McEvoy v. Grp. Health CoOp, 570 N.W.2d 397 (Wis. 1997).

11542 U.S.C. § 300gg-19(a) (2012).

${ }^{116}$ See, e.g., Love v. Fire Ins. Exch., 271 Cal. Rptr. 246 (App. Ct. 1990).

117 See, e.g., Engalla v. Permanente Med. Group, 938 P.2d 903 (Cal. 1997).

${ }^{118}$ See, e.g., Aetna v. Davila, 542 U.S. 200 (2004); Pegram v. Herdrich, 530 U.S. 211 (2000).

11929 U.S.C. § 1132(a) (2012).

${ }^{120}$ Davila, 542 U.S. at 221.

${ }^{121}$ Right to Health Insurance Appeals Process, NAT'L Conference of State Legislatures, http://www.ncsl.org/research/health/right-to-health-insurance-appeals-in-aca.aspx (last updated March 2013).

${ }^{122}$ See Rush Prudential HMO, Inc. v. Moran, 536 U.S. 355, 366 (2002).

${ }_{123} 42$ U.S.C. § 300gg-19(b) (Supp. 2011); Internal Claims, Appeals \& External Review Processes, 76 Fed. Reg. 37,207-37,234 (June 24, 2011) (to be codified in scattered sections of 26, 29 , 45 C.F.R.); Plan Management: Regulations, CTrS. FOR MEDiCARE \& MediCAID Servs., www.cms.gov/cciio/resources/Regulations-and-Guidance/index.html\#Plan\%20Management (last visited March 14, 2014).

${ }^{124}$ Internal Claims, Appeals \& External Review Processes, 76 Fed. Reg. at 37,207-37,234
} 
only for care that offers value for money. ${ }^{125}$ Thus, different decision makers may continue to produce different interpretations of what individual patients are entitled to under their different health plans. ${ }^{126}$ Even where courts issue opinions, their decisions often focus on the specific circumstances of an individual patient and therefore create little precedent for other individual decisions. ${ }^{127}$

\section{The Role of Costs}

Using health insurance as a financing mechanism has the potential to reshape the healthcare delivery system. Today's healthcare system was strongly influenced by what health insurance plans covered and excluded and how much they paid providers. ${ }^{128} \mathrm{~A}$ financing system must decide what services are worth paying for and how much to pay for them. Ultimately, healthcare must be affordable to everyone, not just those who voluntarily buy insurance. With everyone in the system, savings cannot be achieved by risk selection or exclusion from coverage, as with voluntary, commercial insurance. Contributions or premiums of individuals in the group need not correspond to their individual risks; individual contributions, whether in premiums or taxes, may be relatively equal or income based, as long as aggregate revenues are available to pay for the needs of everyone in the group. ${ }^{12}$

This means increased pressure to control healthcare costs, with greater scrutiny of payments to providers and taking value more explicitly into account. ${ }^{130}$ Although a major impetus for the Act was the growing cost of care, ${ }^{131}$ the ACA does not expressly require either reductions or changes in the method of payment for healthcare. ${ }^{132}$ Instead, supporters believe that once everyone is insured, the country will have no choice but to take affirmative steps to control costs. ${ }^{133}$ Since most of the

125 See generally Christopher Newdick, Who Should We Treat? Law, Patients and Resources in the N.H.S. (1995); George J. Annas, Rationing Medical Care, in Standard of CARE: THE LAW OF AMERICAN BIOETHICS 211, 211-217 (1993).

${ }^{126}$ Different insurers may decide to pay for different treatments for the same condition, based on treatment cost, quality or other factors, such as uncertainty concerning the effectiveness of alternatives. For example, attention deficit hyperactivity disorder (ADHD) could be treated with pharmaceutical drugs (Ritalin, Adderall) alone, which appear to be the least costly, with behavioral therapy, which is more expensive, or with a combination of the two. Alan Schwarz, A.D.H.D. Experts Re-evaluate Study's Zeal for Drugs, N.Y. Times (Dec. 29, 2013), www.nytimes.com/2013/12/30/health/adhd-experts-re-evaluate-studys-zeal-for-drugs.html?src=recg.

${ }^{127}$ See William M. Sage, Judicial Opinions Involving Health Insurance Coverage: Trompe L'Oeil or Window on the World?, 31 IND. L. REV. 49, 50-51 (1998).

${ }^{128}$ See generally Wendy K. Mariner, The Affordable Care Act and Health Promotion: The Role of Insurance in Defining Responsibility for Health Risks and Costs, 50 DUQ. L. REV. 271 (2012).

${ }_{120}^{129}$ Mariner, supra note 8, at 441.

${ }^{130}$ Brill, supra note 81 , at $16-17$.

${ }^{131}$ See, e.g., Patient Protection and Affordable Care Act, Pub. L. No. 111-148, § 1563, 124 Stat. 119 (2010) (codified as amended at 43 U.S.C. \$ 18001 (2006)) (Senate finding that "this Act will reduce the Federal deficit between 2010 and 2019"); President Barack Obama, Remarks by the President in State of the Union Address, White House Off. Press Secretary (Jan. 27, 2010), http://www.whitehouse.gov/the-press-office/remarks-president-state-union-address; Barry R. Furrow, Cost Control and the Affordable Care Act: Cramping Our Health Care Appetite, 3 Nev. L.J. 822, 825 (2013); Mariner, supra note 128, at 272.

${ }^{132}$ Furrow, supra note 131, at 845-47 (noting provisions of the ACA that aim to directly or indirectly affect the cost of healthcare, including health insurance exchanges, taxes on high-cost insurance plans, reducing administrative costs, researching comparative effectiveness, promoting prevention and wellness, licensing follow-on biologics, strengthening primary care, establishing quality measures and priorities, promoting high-value care, establishing a center for innovation, enhancing program integrity, reducing avoidable hospital readmissions, promoting accountable care organizations, and facilitating payment bundling).

${ }^{133}$ John E. McDonough, Inside National Health Reform 42 (2011). 
ACA's reforms do not take effect until 2014, noticeable cost control is unlikely for many years. ${ }^{134}$ Competing goals of essential coverage and affordable costs have already challenged the process of making Medicare coverage decisions ${ }^{135}$ and developing a standard Essential Health Benefits package. ${ }^{136}$ This means that the rising cost of care will significantly affect the kind of care that insurance actually pays for, at least for some years to come.

In practice, insurers still bear primary responsibility for controlling costs, but their options are limited. The requirement that insurers cover EHB, however defined, constrains insurers' ability to limit benefits as a way to control costs. The ACA also limits the permissible extent of cost-sharing for patients, which is another traditional way to shift costs. ${ }^{137}$ In principle, insurers could reduce their own administrative costs and profits, but new regulations, such as reporting requirements, ${ }^{138}$ may add to administrative efforts, and for-profit companies are under pressure from investors to increase profits. ${ }^{139}$ One ACA skeptic argues that the ACA's requirement that insurers spend at least eighty percent of premiums on benefits could backfire by encouraging insurers to increase premiums and cover more services for the purpose of preserving executive compensation and profit levels. ${ }^{140}$

This leaves provider payments as a primary target for controlling costs. Although payment is a strong influence on provider behavior, it remains a crude instrument for reducing waste. Insurers do not necessarily have the expertise to finetune payment mechanisms to achieve both financial efficiency and medical effectiveness in individual treatment decisions. This raises the question, noted above, of whether insurance regulators should assume responsibility for overseeing insurer payments to providers. ${ }^{141}$ To complicate matters, if providers in ACOs are responsible for providing care, but specific items and services are not specified in the contract, it will be providers who make the decisions about exactly what the patient receives. ${ }^{142}$ In case of a dispute, who is responsible-the insurer, the provider, or both? Such questions are reminiscent of earlier controversies over medical necessity determinations by managed care organizations. ${ }^{143}$ Should it matter whether the provider has accepted full or partial financial risk for patient care? If the

\footnotetext{
${ }^{134}$ Massachusetts, which has six years of experience with the model for the ACA, recognized the need for cost control early on, but enacted payment reform only in 2012. An Act Improving the Quality of Health Care and Reducing Cost through Increased Transparency, Efficiency, and Innovation, 2012 Mass. Acts ch. 224. Although Massachusetts will not directly control pricing or costs - and cannot control federal payers - the state will set targets for average total per person medical spending growth and require organizations that exceed the targets to submit plans for costsaving measures. $I d$.

${ }_{135}$ Peter J. Neumann \& James D. Chambers, Medicare's Enduring Struggle to Define "Reasonable and Necessary" Care, 367 New ENG. J. MED. 1775, 1777 (2012).

${ }_{136}$ Ctrs. for Medicare \& Medicaid Servs., Essential Health Benefits Bulletin 3 (2011), available

https://www.cms.gov/CCIIO/Resources/Files/Downloads/essential health benefits bulletin.pdf.

${ }^{137} 42$ U.S.C. § 18022(c) (2012). It also prohibits lifetime and annual limits on claims payouts, which limit the risk that the insurer accepts, but are not true methods of cost-shifting. Id. $\S 300 \mathrm{gg}-11$.

${ }^{138}$ Id. $\S \S 300 \mathrm{gg}-17-18$.

${ }^{139}$ See generally Wendell Potter, DeAdly Spin: An InSURAnCe Company Insider SPEAKs

Out on How Corporate PR Is Killing Health Care and Deceiving Americans (1st ed. 2010).

${ }^{140}$ GOLDHILL, supra note 44, at 188 .

${ }^{141}$ See supra notes 78-84 and accompanying text.

${ }^{142}$ See supra note 82.

${ }^{143}$ See generally Marc A. Rodwin, Medicine, Money \& Morals (1st ed. 1993); Mark A. Hall et al., Judicial Protection of Managed Care Consumers: An Empirical Study of Insurance Coverage Disputes, 26 Seton Hall L. ReV. 1055, 1055-68 (1996).
} 
insurance department regulates providers who accept risk, should the department also regulate individual treatment decisions?

\section{CONCLUSION}

Over the past four decades, health insurance has evolved from its original indemnity structure into the primary means of paying for healthcare. The ACA gathers various public benefit programs and private insurance plans into a loosely knit but near universal healthcare payment system. This framework combines aspects of several conceptions of insurance to create a peculiarly American form of social insurance distinct from any single conception. ${ }^{144}$

The ACA is intended to provide near-universal health insurance coverage for the purpose of enabling Americans to obtain needed medical care. In this respect, health insurance performs a governance function by financing and distributing healthcare. The ACA seeks greater consistency in health insurance coverage by regulating the terms of most plans. Such requirements bear some resemblance to product standards in a product conception of insurance. The ACA also regulates the commercial practices of private insurers, suggesting that private health insurance industry is being treated - and should be regulated to some extent-like a modern public utility.

The requirement that private health insurance plans sold on the new health insurance exchanges cover Essential Health Benefits is a major step toward greater consistency in coverage across the population. However, that requirement does not apply to all health plans, and the current definition of Essential Health Benefits lacks specification. As a result, decisions about covered care at the patient level will continue to be made by many different decision makers, just as they are now. Each decision maker, whether public or private, will continue to determine - according to different rules of procedure and interpretation-whether the general categories of benefits include something that a provider recommends or a patient seeks. At the level of payment for patient care, health insurance is likely to operate within the contract conception of insurance.

The ACA should challenge us to think in terms of a new conception of health insurance that could help answer the remaining questions about how to regulate insurers and their plans. Abraham warns that no single conception of insurance provides fully developed normative standards, at least for interpreting the meaning of insurance policies. ${ }^{145}$ Yet, the ACA has taken the first step in the process to provide general standards for health insurance coverage. The next step is to reevaluate the normative standards in insurance law that govern what insurers must do for insureds at the level of patient care.

144 This quasi-social insurance conception of health insurance under the ACA differs from Western European social insurance schemes in its reliance on both public and private programs. Mariner, supra note 8, at 438 (arguing that American health insurance is a separate species of insurance); id. at 449 (comparing the role of private insurers in the US and Western European health insurance systems).

${ }^{145}$ Abraham, supra note 21, at 698 ("[T]he particular lens through which we view insurance law cannot tell us what principles should govern or what policy choices to make."). 